\title{
両心房切開法による巨大左房粘液腫の治療経験
}

林載鳳佐々木秀川本純

65 歳の女性が心不全症状にて受診。心エコー検査にて左房内腫瘍を指摘され，摘出術を行った。腫 瘍は $7 \times 5 \times 4 \mathrm{~cm}, 70 \mathrm{~g}$ の巨大なもので, 組織学的には粘液腫であった。手術は両心房切開法にて行 った. この方法は右側左房切開法や経右房経心房中隔切開法に比べて種々の利点を持つが, 今回のよ うに腫瘍サイズが巨大な場合には, 左房からの腫瘍付着部の指示が確実にできない可能性がある. 腫 瘍摘出後の僧帽弁の評価には術中の経食道心エコー検査が有用であった。 日心外会誌 26 巻 1 号 : 6264 (1997)

Keywords：左房粘液腫, 両心房切開法, 経食道心エコー

\section{A Case of Giant Left Atrial Myxoma Treated by Biatrial Operation}

Saihou Hayashi, Masaru Sasaki, Jun Kawamoto (Department of Cardiovascular Surgery, Chugoku Rosai Hospital, Kure, Japan)

A 65-year-old woman presented with coughing and dyspnea. Giant left atrial myxoma was found by echocardiography. The tumor size was $7 \times 5 \times 4 \mathrm{~cm}$ and its weight was $70 \mathrm{~g}$. The biatrial approach was chosen over left atriotomy or the transseptal approach. However, it may not be possible to decide on the correct incision line in cases of giant tumor. Intraoperative transesophageal echocardiogaphy was useful for evaluation of the mitral valve. Jpn. J. Cardiovasc. Surg. $26: 62-64$ (1997)

心臓腫瘍は稀な疾患である。今回われわれは両 心房切開法による巨大左房粘液腫の治療経験を得 たので，手術手技などに若干の知見を加えて報告 する.

\section{症例}

患者： ，65 歳，女性。

主訴：夜間の呼吸困難.

現病歴：1995 年 9 月上旬より夜間の咳嗽と息 苦しさを感じるようになり，徐々に増悪するため 当院を受診した。

現症：心尖部で拡張期雑音を聴取した。両肺野 で湿性ラ音を聴取した。

検査所見：心エコー検査にて左房の大部分を占 める大きな腫瘍を認めた。

経過：左房粘液腫の疑いにて手術予定とした。 心不全の治療と同時に, CRP $13.8 \mathrm{mg} / \mathrm{dl}$ と高值 をとり肺炎を合併していたのでその治療も併せ行 った。その間 2 度にわたり短時間の意識消失発作

1996 年 4 月 30 日受付, 1996 年 6 月 21 日採用

中国労災病院心臓血管外科 $\bar{T}$ 737-01 呉市㳎多賀谷 1-5-1
と脱力発作があり，腫瘍の嵌頓症状と考えられ た。そのため予定を早めて準緊急に手術を行っ た.

手術所見：まず経食道心エコーを行った。拡張 早期には腫瘍の周囲から左室に流入する血液は著 明な障害を受けていた。拡張終期にはほぼ完全に 僧帽弁輪に嵌頓する状態であった(図 1 )。腫瘍に 対しては両心房切開法にて到達した(図 2 )。まず 左房側から鉗子を挿入して腫瘍付着部を指し示 し，それを目標に右房側から心房中隔と腫瘍を一 塊にして切除する予定であったが，腫瘍が大きす ぎて左房側から適切に指し示すことができず，右 房側から心房中隔に切り込む際の切開部位の同定 が不確実であった。切除した腫瘍を左房側から摘 出した後，心房中隔の欠損部のパッチ閉鎖を行っ た．僧帽弁には腫場の浸潤等はなく特別な処置は 行わなかった。経食道心エコー検査では，ごく軽 微な逆流を認めるものの心不全の軽快により治癒 するものと判断した。術後経過は良好である。

病理所見：摘出腫瘍は $7 \times 5 \times 4 \mathrm{~cm}, 70 \mathrm{~g}$ の巨 大なものであった。腫瘍表面の一部には血栓の付 

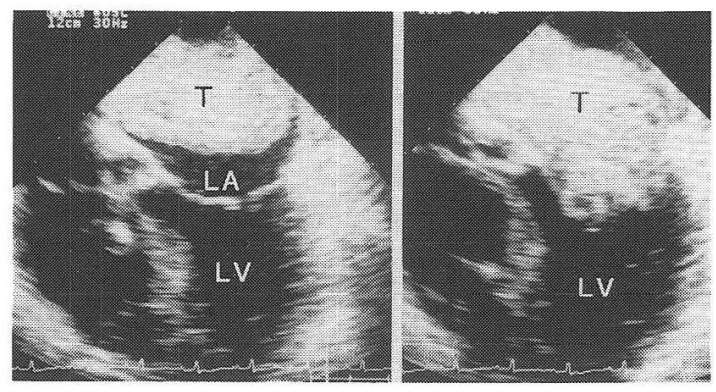

図 1 術中経食道心エコー(摘出前) 拡張早期(左), 拡張終期(右), T : 腫瘍, LV : 左室, $\mathrm{LA}$ : 左房。

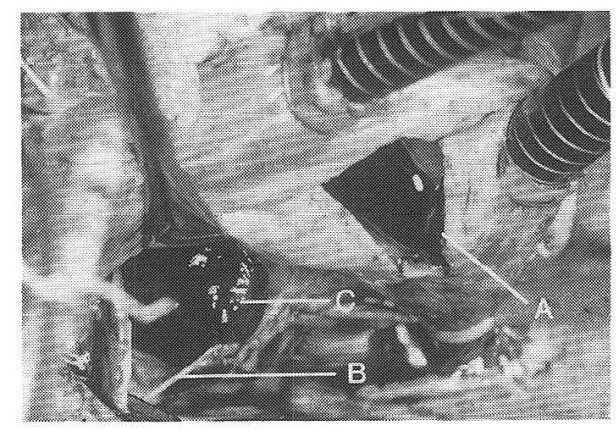

図 2 術中所見(左側が頭側)

四卜部が有房切開 (A), 下部が左房比開(B)で，左房 内に粘液腫の一部 (C)がみられる。

着が認められた。組織学的には良性の粘液腫であ つた。

\section{考案}

心蔵腫咳は稀な疾患で, 約 5 万例の手術例のう ち $0.038 \%$ を占めていたと報告されている 近では心エコーの普及により無症状で偶然発見さ れる症例も増加している。原則として全例が手術 適応となる。その理由は, 第 1 に悪性腫瘍の可能 性があること，第 2 に腫瘍表面に付着する血栓が 脳塞栓の原因となる可能性があること，第３に血 流障害により種々の症状が惹起されること等であ る。第 10 悪性の可能性に関しては，教科書的に は原発性心臓腫瘍のうち 20〜25\%が悪性， 75〜 80\%が良性とされ，悪性の場合には 2 年以内 に80\%が死亡するとされている。組織学的に良 性であっても，腫瘍付着部の不完全切除や術中播 種による再発例も報告されている2)。特徵的な現
象として，術前に脳梗塞を合併した症例では，術 後遠隔期に高率に脳動脈瘤の形成が認められてい る3). 腫瘍塞栓子の血管壁浸潤による現象と推測 される。第3の血流障害に関しては，僧帽弁狭窄 様の心不全の出現のみならず，僧帽弁への嵌頓症 状も重要で，われわれの症例でも嵌頓によると考 えられる一過性の意識消失，脱力発作が術前 2 度 もみられた。

手術術式については，以前は右側左房よりのア プローチ出や経右房経心房中隔よりのアプロー チ5,6) が標準術式とされてきたが，最近になって 左右両心房切開アプローチ法7,8) の報告がなされ るようになってきた。右側左房切開法の欠点は, 腫瘍付着部の切開時に腫痬本体の強い把持を必要 とすることである。また腫晹が大きい場合には十 分な切除範囲をとれないことがある。経右房経心 房中隔切開法の欠点は, 腫晹付着部の切開線が不 正確になりやすいことである。術中心エコー検査 などが使用されているが必ずしも同定は簡単では ないようである。また腫瘍が大きい場合には切開 部からの腫瘍の取り出しが困難で，腫瘍を分割し なければならないこともある。両心房切開法は, 両心房切開を行った後左房側から鉗子を插入して 腫瘍付着部を指し示し，それを目標に右房側から 中隔と腫陽を一塊として切除するものである。左 房側から付着部の指示ができるため腫瘍付着部の 同定は正確であり，切開時にも腫瘍の把持を行な わなくてよい。両心房切開法の短所としては，刺 激伝導障害の可能性と, 手術時間の延長, 出血量 の増大等が考えられるが，いずれも問題にはなら ないと報告されている8).今回われわれはこの両 心房切開法を用いて手術を行ったが，実際に経験 してみると，腫場が大きすぎて左心房のほとんど を占拠するような場合には左房側からの指示を適 切に行うことができず，右房側から中隔に切り込 さ際の切開位置の同定が不正確であった。中等度 までの大きさの腫瘍に対しては両心房切開法が有 用と思われるが，今回われわれが経験したような

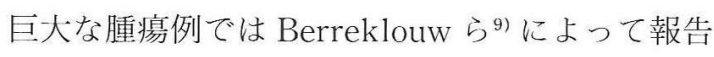
されたcombined superior-transseptal approach が有用ではないかと推測される。このアプローチ 法は僧帽弁疾患の手術に際し, 狭小左心房の場合 
でも僧帕弁の良好な視野が得られるように考案さ れた切開法であるが, 左房粘液腫に対しても 1995 年に Vigano ら ${ }^{10)}$ によって症例報告が行わ れており良好な視野であったとされる。すなわち 両心房切開法においても左房側からの指示は間接 的なものにとどまるのに対して, combined superior-transseptal approach法は, 最初に左 房上壁に切開を加えて展開することにより，腫瘍 付着部を直視下にとらえることが可能となる。こ の切開法の欠点として洞結節動脈損傷に伴う洞機 能不全症候群の発生の危険がないわけではない が，臨床実地上でその発生頻度は低く，たとえ発 生した場合でも短期間のうちに側副伝導路によっ て代償されることが多いとされている ${ }^{11,12)}$. 本腫 隍の発生部位のほとんどは心房中隔であり，かつ その付着部は小さいことが多いので，僧帽弁狭窄 あるいは僧帽弁嵌頓の症状を呈していても弁に対 する同時手術の必要性は少ないようである。手術 時の僧帽弁の評価には術中経食道心エコー検查法 が有用であった。

\section{文献}

1) Reece, I. J., Cooley, D. A., Frazier, O. H. et al. : Cardiac tumors. J. Thorac. Cardiovasc. Surg. 88: 439-446, 1984.

2）小久保光治，広瀬光男，小池茂文ほか：左房粘液 腫再発症例。日胸外会誌 35：1910-1914, 1987.

3）岡田健志, 江石清行, 小坂井嘉夫ほか：心臓粘液 腫 38 例の外科治療とその長期遠隔成績の検討. 日胸外会誌 43：793-796, 1995.
4) Larsson, S., Lepore, V. and Kennergren, C. Atrial myxomas: results of 25 years' experience and review of the literature. Surgery 105 : 695-698, 1989.

5) Bortolotti, U., Maraglino, G., Rubino, M. et al. : Surgical excision of intracardiac myxomas: a 20-year follow up. Ann. Thorac. Surg. 49 : 449$453,1990$.

6) Sellke, F. W., Lemmer, J. H., Vandenberg, B. F. et al. : Surgical treatment of cardiac myxomas: long-term results. Ann. Thorac. Surg. 50 : 557-561, 1990.

7) Kabbani, S. S., Jokhadar, M., Meada, R. et al. : Atrial myxoma : report of 24 operations using the biatrial approach. Ann. Thorac. Surg. 58: 483-488, 1994.

8) Jones, D. R., Warden, H. E., Murray, G. F. et al. : Biatrial approach to cardiac myxomas: a 30-year clinical experience. Ann. Thorac. Surg. 59: 851 856, 1995.

9) Berreklouw, E., Ercan, H., Schonberger, J. P. et al. : Combined superior-transseptal approach to the left atrium. Ann. Thorac. Surg. 51 : 293295, 1991.

10) Vigano, M., Grande, A. M. and Gaeta, R. : Superior transseptal approach to left atrial myxomas. Ann. Thorac. Surg. 60 : 1860-1861, 1995.

11）申 範圭, 東 茂樹, 井関治和ほか：Superior se ptal approach による僧帽弁手術の手術成績と術 後洞機能の検討. 日胸外会誌 44：111-114, 1996.

12) Utley, J. R., Leyland, S. A. and Nguyenduy, T. Comparison of outcomes with three atrial incision for mitral valve operations. J. Thorac. Cardiovasc. Surg. 109 : 582-587, 1995. 